\title{
Statyba
}

\section{RESEARCH ON THE STABILITY OF BUILDING MIXTURE STRUCTURE}

\section{J. Deltuva}

To cite this article: J. Deltuva (2001) RESEARCH ON THE STABILITY OF BUILDING MIXTURE STRUCTURE, Statyba, 7:6, 441-445, DOI: 10.1080/13921525.2001.10531770

To link to this article: https://doi.org/10.1080/13921525.2001.10531770

曲 Published online: 30 Jul 2012.

Submit your article to this journal $₫$

III Article views: 49 


\section{STATYBINIŲ MIŠINIŲ STRUKTŪROS TYRIMAS}

\section{J. Deltuva}

Kauno technologijos universitetas

\section{Ivadas}

Kiekviena dirbtinè statybinẻ medžiaga tam tikroje gamybos stadijoje yra mišinys. Mišinio paruošimo stadijoje komponuojama medžiagos cheminè ir mechaninè sudètis, sudaromos prielaidos fizikiniams, cheminiams ir technologiniams procesams vykti tokia kryptimi, kad būtu gautas norimu savybiụ galutinis produktas. Vienas iš plačiausiai naudojamu heterogeniniu mišinių yra nesukietejęs betono mišinys ir kietasis mišinys - betonas.

Iprastojo betono kokybei îvertinti galiojantys standartai reglamentuoja tik vienos is svarbiausiuju savybių - stiprio rodiklio patikimumą, nustatytą pagal išbandytų bandiniu skaičiu ir apskaičiuotą pagal stiprio kitimo variacijos koeficienta. Tai yra labai svarbu, bet dažnai to nepakanka. Betono stiprumą galima užtikrinti ìvairiais būdais - keičiant mišinio sudèti, ypač vandens ir cemento santyki, užpildu granuliometrinę sudèti ir taikant specialias technologines priemones.

Kol kas betono struktūros stabilumo patikimumas tiesiogiai nereglamentuojamas, o apibūdinamas tik netiesioginiu bandymu rodikliais - pagal vandens igèrio kinetiką uždaruju ir atviruju poru kieki, atsparumą šalčiui ir kt. Savaime suprantama, kad kiekvienas šiu rodikliu savaip ir tik iš dalies įvertina betono struktūrą. Kita vertus, netiesioginiais būdais yra ivertinamos betono struktūros tobulumo ar netobulumo pasekmès, bet ne pati struktūra. Pastaruoju metu vis plačiau taikomi tam tikros paskirties specialieji betonai: didelio stiprumo; nelaidūs vandeniui; atsparūs šalčiui; atsparūs šalčio ir drusku poveikiui; atsparūs cheminiam poveikiui; atsparūs dilimui; atsparūs aukštai temperatūrai (iki $250^{\circ} \mathrm{C}$ ) povandeninio betonavimo ir $\mathrm{kt}$. Sie betonai vienas nuo kito skiriasi savita struktūra, todèl ir vienodos struktūros užtikrinimas juos gaminant yra ypač svarbus.

Betoniniu ir gelžbetoninių konstrukciju skaičiavimui greta betono stiprio charakteristikos reikalingi ir kitu savybiu rodikliai: tamprumas, deformatyvumas, atsparumas kai kuriems specifiniams mechaniniams, cheminiams bei fizikiniams poveikiams. Prognozuojant betono atsparumą minètiems poveikiams, dažnai taikomi panašumo teorijos ir modeliavimo metodai. Todel betono struktūros, vienodumo, panašumo ir patikimumo aprašymui turi būti nustatyti ir taikomi tokie vertinimo kriterijai, kurie atitiktų panašumo bei modeliavimo teorijos reikalavimus.

Kiekvienos sistemos patikimumo analizè turi remtis tiksliomis ir vienareikšmémis sąvokomis bei terminais. Tam geriausiai tinka tikimybiu teorijoje vartojamos sąvokos ir terminai.

Žinant, kad medžiagos kokybès patikimumas yra technologinè savybè, remiantis patikimumo teorijos dèsniais, galima suformuluoti mišinio, kaip medžiagos, struktūros stabilumo patikimumo apibrěžima.

Statybinių grūdètuju mišinių struktūros stabilumo patikimumą galima apibrěžti taip: tai tikimybè, kad, esamomis sąlygomis, per tam tikrą laikotarpi bus pagamintas vienodos sudéties, vienodos struktūros ir vienodụ savybiu reikiamas mišinio (medžiagos) kiekis.

Sistemoje atsiradusią neatitikti reikia suprasti kaip laiko funkcija, kurią galima išreikšti taip [1]:

$$
P(t<t)=F(t), \quad t>0,
$$

$\boldsymbol{t}$ - atsitiktinis dydis, apibūdinantis sistemą iki neatitikties; $F(t)$ - tikimybé, kad sistema be neatitikties bus naudojama iki laikotarpio $t$.

Tikimybé, kad sistema laikotarpi $t$ bus naudojama be trukdžiŭ, galima užrašyti taip:

$$
R(t)=1-F(t)=P(t>t),
$$

$R(t)$ - tikimybè, kad sistema dirbs be trukdžių.

Medžiagos struktūros vienodumo ar panašumo patikimumas gali būti ivertinamas dviem etapais: pagal paruošimo operacijas arba pagal galutinio produkto, nustatyto eksperimentiniu bũdu, patikimumą. Gamybos ope- 
racijų patikimumo nustatymo būdas yra pranašesnis už patikimumo nustatymą pagal galutini produktą tuo, kad greičiau galima aptikti galutinio produkto neatitikties priežastis, jei tokių yra, arba rasti rezervų technologiniams procesams tobulinti.

Šio darbo tikslas - taikant struktūrinių elementu metoda, sudaryti diskretinių dydžių, kuriais galima būtų ivertinti betono struktūros stabilumą, sistemą ir kad per reikiamą gamybos laikotarpi mišinių ir gaminiu struktūra būtų ivardyta kaip patikimai vienoda.

\section{Betono komponentų kai kuriụ savybių kitimo ribos}

Pagal galiojančius betono atitikties vertinimo standartus jis laikomas vienodu, jeigu $\mathfrak{i}$ mišini dedama vienoda komponentų koncentracija ir jis buvo pagamintas vienodomis sąlygomis. Tačiau dažnai neịvertinamas realus komponentu savybiu kitimas todèl, esant tai pačiai komponentų koncentracijai, gaunamas skirtingos struktūros ir savybiu betonas. Leistinas komponentų savybių kitimas yra nevienareikšmis. Leistini platūs rodiklių nuokrypiai komponentu gamybos metu, tačiau betono gamyboje turètu būti kur kas mažesni tu pačių rodikliu nuokrypiai.

Iš kai kurių betono ir gelžbetonio įmonių surinkus duomenis apie betono komponentus, nustatyta ši medžiagu techniniu rodikliu, kurie turi itakos betono struktūrai, sklaida. I gamyklas tiekiamo tos pačios CEM 42,5 klasès skirtingu partijų cemento stiprio sklaidos ribos $10 \mathrm{MPa}$. Vien tik dèl skirtingo cemento stiprio betono stipris gali kisti iki 30\%. Norint sumažinti betono stiprio kitima, reikètu koreguoti mišinio sudeti, t. y. keisti betono struktūrą.

Kur kas didesnè užpildụ savybiụ rodikliu sklaida. Stambujji užpildą dažniausiai sudaro tik dviejų frakciju dalelès, todèl jų granuliometrinè sudètis turètų nedaug kisti. Bandymai parodè, kad realiai taip nèra, nes, stambuji užpildą sijojant per vidutinio tankumo sieta, išbiros masès variacijos koeficientas siekia 62\%. Dar didesnè smèlio stambumo rodikliu sklaida. Eksperimentais nustatyta, kad betonui naudojamo to paties telkinio polifrakcinio smėlio (0/4 mm frakcijos) stambumas yra nevienodas. Šs nevienodumas atsiranda dèl žaliavos skirtingos granuliometrinés sudėties, geologinès sanklodos nevienodumo, perdirbimo technologijos savitumo ir kitu priežasčių.
Betono mikro- ir makrostruktūros formavimui didelès ịtakos turi smulkioji smèlio frakcija $(0 / 0,25 \mathrm{~mm})$. Kai jos nèra, susidaro cementinès tešlos sankaupu tarp stambesnių kaip $0,25 \mathrm{~mm}$ dalelių užpildo. Tarp tų dalelių, kietejjant cementui, dèl fizikinių ir cheminių procesų gali atsirasti lokalinių mikroplyšių.

Išanalizavus smèlio, gaunamo iš to paties tiekèjo, granuliometrinę sudèti (keturiolika partiju), nustatyta, kad smèlio išbiros per $0,25 \mathrm{~mm}$ akelių sietą kitimo ribos labai plačios. Jos masès variacijos koeficientas $66,50 \%$. Eksperimentais nustatyta, kad gaminant vienos atmainos betoną smulkiuju daleliu kartais yra per daug, o kartais - per mažai. Dẻl šios priežasties faktiškai gaunamas skirtingos struktūros ir skirtingu savybiu betonas, nes gaunamas skirtingas betono stipris, vandens igèris ir pan.

Smèlio granuliometrinè sudètis turi didelès itakos cemento sąnaudoms ir betono struktūrai. Kitoje gamykloje nustačius per pusę metų tiekto 28 partijų smélio piltini tanki gauta, kad jis kinta nuo $1430 \mathrm{~kg} / \mathrm{m}^{3}$ iki $1620 \mathrm{~kg} / \mathrm{m}^{3}$, arba santykinis tankis kinta nuo $0,563 \mathrm{iki}$ 0,616 . Tai rodo, kad suprojektuotas betono mišinių sudètis gamybos metu būtina koreguoti ir optimizuoti, atsižvelgiant $\mathfrak{i}$ gaunamu komponentų techninius rodiklius: naudojamo smèlio stambumą, santykinị tankị, cemento aktyvuma, betono reikiamą stipri ir fizikines savybes. Tačiau kartu turètų būti atitinkamai kontroliuojama ir betono struktūra, bet tokio reikalavimo betono atitikties standarte nèra.

\section{Betono mišinių makrostruktūros projektavimo principai}

Projektuojant tankios struktūros betono mišinio racionalią sudètí, būtina optimizuoti užpildų granuliometrinę sudèti. Optimizavimui galima taikyti kelis būdus: eksperimentini, pagal sudarytus grafikus, pagal stambumo modulių santykius, pagal stambiuju ir smulkiujų daleliu vidutinių skersmeny santyki ir kitus. Optimizavimas pagal stambiojo ir smulkiojo užpildo santykị turi privalumų, nes pagal šių dalelių skersmenis galima apskaičiuoti struktūrinių elementų matmenis ir analizuoti betono makrostruktūrą. Skaičiavimus tikslinga atlikti tokia tvarka:

1. Apskaičiuojamas viso užpildų mišinio santykinis tankis $\rho_{s}$, pagal (3) formulę turètų būti $\rho_{s} \geq 0,75$. Jeigu gautas rezultatas netenkina, reikia keisti $(D / d)$ santyki: 


$$
\rho_{s}=a \ln (D / d)+b,
$$

$D$ ir $d$ - atitinkamai stambiuju ir smulkiuju dalelių vidutiniai skersmenys; $a$ ir $b-$ koeficientai ( $a=0,063$; $b=0,63$ ).

2. Apskaičiuojamas užpilde esančių tuštymių tūris $T \mathrm{l} / \mathrm{m}^{3}$ mišinio:

$$
T=\left(1-\rho_{s}\right) 1000
$$

3. Apskaičiuojamas cementinès tešlos tūris, reikalingas užpildo tuštymèms užpildyti. Projektuojant tankios struktūros betono mišinị, cementinès tešlos tūris turi būti šiek tiek didesnis už užpilde esančiu tuštymių tūrị. Jis gali būti apskaičiuojamas pagal tokią formulę:

$$
V_{\text {t.uz. }}=\left(1-\rho_{s}\right) \beta 1000,
$$

$V_{t, u z ̌}-$ užpildo tuštymiu tūris, $1 / \mathrm{m}^{3} ; \beta$ - tuštymiu perpildymo koeficientas, parenkamas atsižvelgiant i norimo gauti mišinio slankumą ir struktūrą.

Apskaičiuojant cementinès tešlos tūrị, kai užpildai sausi, pridedamas vandens kiekis užpildu paviršiui sudrèkinti ir paviršiniam igèrimui, o kai užpildai šlapi, atitinkamai ivertinamas juose esančio vandens kiekis.

4. Cemento kiekis apskaičiuojamas pagal tipines formules, atsižvelgiant i projektuojamo betono stipri, cemento klasę, $V / C$ santyki ir reikalinga betono mišinio slankumą.

Betono stiprumui ivertinti galima taikyti supaprastintą funkcinę priklausomybę, kuri bendruoju atveju būtų tokia:

$$
R_{b}=f\left(A R_{c}\right),
$$

$A$ - proporcingumo koeficientas, ivertinantis užpildų kokybe, $V / C$ santyki ir kitus veiksnius, $R_{c}$ - cementinio akmens stipris.

Iš (6) formulès matyti, kad betono stipris tiesiogiai priklauso nuo cemento stiprio, jei kitos sallygos yra vienodos. Be to, nuo cemento klasès iš dalies priklauso ir betono mikrostruktūra. Tačiau šio tipo ir kitos panašios formulès neivertina projektuojamo betono struktūros, nuo kurios priklauso kitos labai svarbios fizikinès savybès, pvz., tamprumas, vandens igèris, atsparumas šalčiui ir kitos.

\section{Mišinio struktūriniai elementai}

Betonas yra polistruktūrinè medžiaga ir reikia analizuoti kiekvieno lygmens struktūrą. Be to, tai yra kietasis grūdètas mechaninis mišinys. Pagal medžiagotyros sampratą tokių medžiagu erdvinè struktūra apibūdina- ma ją sudarančiu dalelių arba iš jų susidariusių bloku, kurie gali būti apibūdinti kaip diskretiniai tos medžiagos struktūriniai elementai, susidèstymu ir ryšiais tarp jų. Struktūrinis elementas - mažiausias medžiagos narvelis, ị kurio sudètị ieina visi tą medžiagą sudarantys komponentai tomis pačiomis proporcijomis kaip ir visame tūryje. Struktūrini elementą sudaro viena vidutinio skersmens stambioji dalelè ir jai priskirtas gaubiantysis sluoksnis, sudarytas iš smulkiuju daleliu ir skystųju komponentų.

Norint apskaičiuoti betono mišinio struktūrinio elemento parametrus, būtina diskretiškai nustatyti stambiojo ir smulkiojo užpildo dalelių vidutinius skersmenis. Iprastojo betono stambiuoju užpildu laikytinos stambiausios dalelès, kurios sudaro $50 \%$ viso užpildo tūrio, o likusius $50 \%$ priskiriamos smulkiosioms. Kai naudojamas trūkios granuliometrinès sudèties užpildas, stambusis užpildas gali sudaryti daugiau arba mažiau kaip 50\%. Kiekvienu konkrečiu atveju ji reikia atitinkamai apskaičiuoti. Stambiojo ir smulkiojo užpildo daleliu skersmenys apskaičiuojami pagal šių užpildu granuliometrines sudetis $[2,3]$.

Betono mišinio skaičiuojamaji struktūrini elementą aproksimavus i kubelio forma, jo kraštinès ilgi galima apskaičiuoti pagal tokią funkcinę priklausomybę:

$$
A=D\left(\pi /\left(6 \varphi_{\check{z}}\right)\right)^{1 / 3} \approx 0,8 D / \varphi_{\check{z}}^{1 / 3},
$$

$A$ - struktūrinio elemento kraštinès ilgis, mm; $D$ - struktūrinio elemento branduolio skersmuo, $\mathrm{mm} ; \varphi_{\bar{z}^{-}}$stambiojo užpildo tūrinè koncentracija mišinyje.

Ivertinus tai, kad stambiojo užpildo koncentracija betono mišinyje rekomenduojama nuo 0,35 iki 0,45 , šias vertes ịrašius $\mathrm{i}$ (7) formulę, gaunama:

$$
A=(1,04 \ldots 1,14) D \text {. }
$$

Smulkiojo užpildo dalelių, kurios gali tilpti i struktūrinio elemento ribas, didžiausias skersmuo $d$ gali būti apskaičiuotas pagal (8) funkcinę priklausomybę:

$$
d_{\max }=A\left(3^{1 / 2}-1\right) /\left(3^{1 / 2}+1\right) \approx 0,268 A .
$$

Vidutinis didžiausias smulkiojo užpildo dalelių skersmuo turètu būti apie 1,8 karto mažesnis, tai būtų:

$$
d=0,15 \mathrm{~A} \text {. }
$$

Analogiškai galima apskaičiuoti betono mišinio skiedininès dalies struktūrinio elemento kraštinès ilgi:

$$
a=d\left(\pi /\left(6 \varphi_{s}\right)\right)^{1 / 3} \approx 0,8 d / \varphi_{s}^{1 / 3},
$$

$a$ - skiedininès dalies struktūrinio elemento kraštinès ilgis, mm, $d$ - stambesniuju smèlio dalelių (kurios su- 
daro $50 \%$ smélio tūrio) vidutinis skersmuo, $\mathrm{mm} ; \varphi_{s}$ stambesniujų smèlio dalelių tūrinè koncentracija skiedininèje dalyje:

$$
\varphi_{s}=V_{s} /\left[V_{s}+2\left(V_{c}+V_{v}+V_{p}\right)\right],
$$

$V_{s}, V_{c^{\prime}} V_{v} V_{p}$ - atitinkamai smèlio, cemento, vandens ir poru tūriai, $1 / \mathrm{m}^{3}$.

Nustačius cemento dalelių granuliometrinę sudèti ir stambiuju bei smulkiujų daleliu skersmenis, galima apskaičiuoti cementinès tešlos struktūrinio elemento geometrinius matmenis pagal tokią empirinę formulę:

$$
\begin{gathered}
A_{c}=D_{c}\left[\left(\pi / 3\left(1+\rho_{c}(V / C)\right)\right]^{1 / 3}, \mu \mathrm{m}\right. \\
A / D_{c}=\left[(\pi / 3)\left(1+\rho_{c}(V / C)\right)\right]^{1 / 3},
\end{gathered}
$$

$A_{c}$ - cemento tešlos struktūrinio elemento kraštinès ilgis, $\mu \mathrm{m} ; D_{c}$ - cemento stambesniuju dalelių vidutinis skersmuo, $\mu \mathrm{m} ; \rho_{c}$ - cemento dalelių tankis, $\mathrm{g} / \mathrm{cm}^{3}$.

Vienas iš betono struktüros rodikliụ gali būti struktūrinių elementų skaičius tūrio vienete, kuris apskaičiuojamas pagal (13) formulę. Šis rodiklis taikytinas vertinant originalo ir prototipo matmenų mastelio itaką nustatant gaminiu stiprumą ir deformacijas:

$$
N=V \varphi / v
$$

$N$ - struktūrinių elementų skaičius tūrio vienete; $V$ tūrio vieneto tūris, $\mathrm{dm}^{3}, \mathrm{~cm}^{3}, \mathrm{~mm}^{3} ; v$ - vieno struktūrinio elemento branduolio tūris, $\mathrm{cm}^{3}, \mathrm{~mm}^{3} ; \varphi$ - struktūrinių elementų branduolių tūrinè koncentracija.

Remiantis šiais ir ankstesniais tyrimais [4], galima suformuluoti monostruktūrinių ir polistruktūriniu mišinių (medžiagu) struktūros vienodumo apibrèžimą:

Monostruktūrinių grūdètuju mišiniu (medžiagu), pagamintu vienodomis sąlygomis, struktūra yra patikimai vienoda, jei struktūriniai elementai yra vienodo didumo ir vienodo tankumo.

Polistruktūrinių grūdètujų mišiniu (medžiagu), pagamintų vienodomis sąlygomis, struktūra yra patikimai vienoda, jei ju atitinkamo struktūros lygmens struktūriniai elementai yra vienodo didumo ir vienodo tankumo.

Struktūrinių elementų didumas apibūdina apibendrintus struktūros geometrinius parametrus, o elementu tankis - fizikinius. Šie rodikliai gali būti analitiškai apskaičiuoti ir pagal matematinès statistikos bei tikimybiu teorijos dèsnius nustatytas mišinio (medžiagos) struktūros vienodumo patikimumas.

Analizuojant (7), (9) lygtis, galima pastebèti, kad struktūrinio elemento tūris priklauso nuo branduolio skersmens bei jo tūrio dalies elemente ir nuo gaubiančiojo sluoksnio santykinio tankio. Kai gaubiančiojo sluoksnio tankis didejja, struktūrinio elemento užimamas tūris mažẻja, tačiau didèja jo santykinis tankis. Iš to galima padaryti tokias labai svarbias išvadas:

1) mišinyje didinant stambiujų daleliụ tūrinę koncentraciją iki $(\varphi \leq \pi / 6)$, jo kietosios fazès santykinis tankis dideja;

2) turi būti išlaikyta sąlyga, jog smulkiuju dalelių skersmuo turi būti mažesnis už tuštymių, kurios susidaro tarp stambiuju dalelių, skersmeni pagal (8);

3) didejjant stambiuju užpildu koncentracijai, gali būti naudojamas smulkesnis smèlis arba, atvirkščiai, naudojant smulkesni smèli, tikslinga $\mathfrak{i}$ mišini dèti daugiau stambiujų užpildų;

4) užpildo struktūrinio elemento geometriniai matmenys mažèja, didejjant gaubiančiojo sluoksnio tankiui.

Analogiškai pagal struktürinius elementus galima analizuoti ir cementinès tešlos mikrostruktūrą. Išvardytieji rodikliai yra irankiai betono mikro- ir makrostruktūrai analizuoti, modeliuoti, ieškoti priklausomybiụ tarp betono struktūros ir atitinkamų jo savybių dèsningumo.

\section{Išvados}

1. Pateiktas struktūrinių elementu metodas gali būti taikomas, kai norima diskretiškai apskaičiuoti, palyginti ar modeliuoti betonų arba kitokiu statybinių mišinių struktūras bei apskaičiuoti ju atitinkamo lygmens struktūros vienodumo rodiklius.

2. Taikant struktūriniu elementų metodą, galima nustatyti užpildų granuliometrinès sudèties leistinuosius nuokrypius, kad būtu galima užtikrinti reikiamą vienodą betono makrostruktūrą ir reikiamus stiprumo bei deformatyvumo savybių rodiklius.

3. Betono struktūros vienodumo patikimumas turi būti reglamentuojamas pagal jo atmainas ir tai, kuriam tikslui jis naudojamas. Tai ypač svarbu laikančiosioms gelžbetoninèms konstrukcijoms, kai reikia, kad realios betono deformacijos atitiktų apskaičiuotas leistinąsias.

\section{Literatūra}

1 К. Капур, Л. Ламберсон. Надежность и проектирование систем. Москва: Мир, 1980. 604 с.

2 H. U. Litzner, L. Meyer. Beton nach neuem Regelwerk // Beton, 11/2000, p. 628-632. 
3 Reschke, E. Siebel, G. Thielen. Einflüss der Granulometrie und Reaktivität von Zement und Festigkeits- und Gefügeentwiclung von Mörtel und Beton (Teil 1) // Beton, 12/1999, p. 719-724, (Teil 2) 1/2000, p. 47-50.

4 J. Deltuva. Heterogeniniu statybiniu mišiniu sandara ir savybès. Kaunas: Technologija, 1998. 263 p.

Iteikta $2001 \quad 1130$

\section{RESEARCH ON THE STABILITY OF BUILDING MIXTURE STRUCTURE}

\section{J. Deltuva}

\section{S u m m a r y}

The aim of this work is to establish the system of quantities that would be suitable to evaluate the stability of the structure of concrete in order to assure that the structure of mixtures and building articles is uniform during the given production period.

Concrete is a polystructured material and therefore its structure must be analyzed at all levels. According to concept of the materials science, the spatial structure of such a material is defined by the arrangement and interconnections of component particles or component blocks that can be considered as discrete structural elements. A structural element is the smallest cell of material that contains all the material ingredients at the same proportions as the entire volume. A structural element is formed by a large particle of medium size and the interface layer is of small particles and liquid components.

The presented method may be applied when it is desirable to compute, compare or model the structures of concrete and other building mixtures and calculate the structural uniformity indices.

According to given uniformity of macrostructure, it is possible to determine by the use of structural elements the admissible aggregate grain-size tolerances, in order to achieve the uniform structure, the strength and deformability.

The reliability of the uniformity of a concrete structure must be regulated according to its type and function; it is especially important for load bearing reinforced concrete where a real deformation of concrete must conform to the calculated allowable one.

Juozas DELTUVA. Doctor, Associate Professor. Dept of Building Materials. Kaunas University of Technology (KTU). Studentu g. 48, 3031 Kaunas, Lithuania.

E-mail: lab0960@saf.ktu.lt

Doctor (1966). In 1969-79 and 1988-95, Head of Dept of Building Materials (KTU). In 1995-99, Head of Research Laboratory of Building Materials and Structures. Research interests: mineral raw materials, their remaking, structural analysis of heterogeneous materials. 